\title{
Positive State Obligations under European Law: A Tool for Achieving Substantive Equality for Sexual Minorities in Europe
}

\author{
Alina Tryfonidou*
}

\begin{abstract}
This article seeks to examine the development of positive obligations under European law in the specific context of the rights of sexual minorities. It is clear that the law should respect and protect all sexualities and diverse intimate relationships without discrimination, and for this purpose it needs to ensure that sexual minorities can not only be free from state interference when expressing their sexuality in private, but that they should be given the right to express their sexuality in public and to have their intimate relationships legally recognised. In addition, sexual minorities should be protected from the actions of other individuals, when these violate their legal and fundamental human rights. Accordingly, in addition to negative obligations, European law must impose positive obligations towards sexual minorities in order to achieve substantive equality for them. The article explains that, to date, European law has imposed a number of such positive obligations; nonetheless, there is definitely scope for more. It is suggested that European law should not wait for hearts and minds to change before imposing additional positive obligations, especially since this gives the impression that the EU and the European Court of Human Rights (ECtHR) are condoning or disregarding persistent discrimination against sexual minorities.
\end{abstract}

Keywords: Positive obligations, sexual minorities, sexual orientation, European law, human rights

\section{Introduction}

Historically, persons with non-heterosexual sexualities namely, lesbian, gay and bisexual (LGB) persons - were considered to be subjects of non-belonging, the 'other', as members of an 'out-group', ${ }^{1}$ and, thus, judged as not worthy of rights. The dominance of heterosexuality as the only legitimate form of sexual orientation and the silencing of all other discourses of sexuality have traditionally legitimised exclusionary laws and policies that completely ignored the existence of sexual minorities and relegated them to a second-rate position. Nonetheless, as human beings, persons with non-heterosexual sexualities have the same human rights as everyone else. This has been recognised in European law (i.e. the law stemming from the European Convention on Human Rights (ECHR) and the European Union (EU)). Accordingly, as a first move towards equality for persons with non-heterosexual sexualities, European States have been required - as part of their obligations arising from European law - to fulfil their (negative) obligations towards sexual minorities, by refraining from violating their fundamental human rights: this has been achieved through, inter alia, the decriminalisation of same-sex acts (ECHR) ${ }^{2}$ the equalisation of the age of consent $(\mathrm{ECHR})^{3}$ and the prohibition imposed on the State itself of any discriminatory practices based on sexual orientation (ECHR \& EU law). ${ }^{4}$ At the same time, LGB persons also need specific guarantees against discrimination if they are to enjoy substantive equality with everyone else. This requires the imposition of positive obligations on States, requiring them to protect LGB persons from discrimination and other hostile acts perpetrated by others that are based on their non-heterosexual sexuality, as well as to promulgate laws that extend to sexual minorities access to numerous civil, social and cultural rights granted (by default) to their heterosexual peers, such as the right to have their relationships legally recognised.

This article seeks to examine the development of positive obligations under European law in the specific context of the rights of sexual minorities. ${ }^{5}$ Such obligations

* Alina Tryfonidou is Professor of Law, University of Reading. I would like to thank Professor Kristin Henrard, the participants at the international conference 'Positive state obligations concerning fundamental rights and "changing the hearts and minds'", 30-31 January 2020, at Erasmus University Rotterdam, and the two anonymous reviewers for their insightful feedback on previous drafts of this article. Needless to say, all errors remain mine.

1. For an argument that international human rights law must develop a positive State obligation to counter the dehumanisation of out-groups, given that there is a clear connection between the dehumanisation of out-groups and violations of the human rights of members of such groups see Berry in this special edition.

2. Dudgeon v. United Kingdom, no. 7525/76, 22 October 1981; Norris v. Ireland, no. 10581/83, 26 October 1988; Modinos v. Cyprus, no. 15070/89, 22 April 1993.

3. Sutherland v. United Kingdom, no. 25186/94, Commission report, 1 July 1997; L and V v. Austria, nos. 39392/98 and 39829/98, 9 January 2003.

4. Salgueiro da Silva Mouta v. Portugal, no. 33290/96, 21 December 1999; Case C-528/13 Léger ECLI:EU:C:2015:288.

5. For the purposes of this article, the phrase 'sexual minorities' should be taken to refer to persons with a non-heterosexual sexual orientation and, in particular, LGB persons. Although in many instances - namely, when they are in an opposite-sex relationship - bisexual persons will 
can be used - together with negative obligations - as a tool to counter prejudice against sexual minorities. By imposing positive obligations on States to make provision in their legislation for sexual minorities in a way that ensures that substantive equality is achieved between them and the majority, European law can aspire to change hearts and minds not only among the general population of States but, also, among politicians and lawmakers. This is because it demonstrates that persistent discrimination against sexual minorities can no longer be permitted or tolerated, whether this is perpetrated by the State or by other individuals.

The development of positive obligations under European law is a topic that is almost completely uncharted in the existing literature: although there is some literature focusing on the positive obligations imposed on Member States by the ECHR in general, ${ }^{6}$ there is next to nothing on this particular topic (i.e. positive obligations) in the specific context of sexual minority rights, either under the ECHR or under EU law.

The two supranational European courts (the European Court of Human Rights (ECtHR) and the Court of Justice of the EU (CJEU)) have not provided an authoritative definition of positive obligations, nor does the ECHR or the constituent EU Treaties make any reference to - let alone define - positive obligations. Hence, unlike negative obligations that, in most instances, are derived from express textual requirements of the Treaties, positive obligations are very rarely explicitly articulated in the various instruments: therefore, they are either implied judicial creations ${ }^{7}$ or - in the case of the EU - they are laid down in secondary legislation. Put simply, positive obligations impose on States the duty to do something - to 'take action' ${ }^{8}$ - or provide something to individuals or to protect them from other individuals: they are obligations 'to take positive steps or measures to protect' the rights of individuals. ${ }^{9}$ They can encompass procedural/institutional duties to undertake specific acts (e.g. investigations), obligations to amend domestic laws (e.g. in order to criminalise specific actions and in

not be (legally) disadvantaged in the same way as gays and lesbians are (e.g. availability of marriage), in the majority of instances they can potentially be disadvantaged in the same way and, thus, the article treats LGB persons as one category for its purposes. In any event, in court jurisprudence, it is rarely, if ever, specified if the applicant is L/G or $B$, as the claim usually is that they are disadvantaged as a result of the fact that they are in a same-sex relationship or that they are attracted to persons of the same sex.

6. See, most fundamentally, A. Mowbray, The Development of Positive Obligations under the European Convention on Human Rights by the European Court of Human Rights (Hart, 2004); D. Xenos, The Positive Obligations of the State under the European Convention of Human Rights (Routledge, 2012). See, also, M. Pitkänen, 'Fair and Balanced Positive Obligations - Do They Exist?', 5 European Human Rights Law Review 538 (2012); A.I.L. Campbell, 'Positive Obligations under the ECHR: Deprivation of Liberty by Private Actors', 10 Edinburgh Law Review 399 (2006).

7. Pitkänen, above n. 6 , at 539

8. Dissenting Opinion of Judge Martens in Gül v. Switzerland, no. 23218/93, 19 February 1996.

9. K. Starmer, European Human Rights Law: The Human Rights Act 1998 and the European Convention on Human Rights (Legal Action Group, 1999), at 194. this way protect individuals from other individuals or to extend certain rights to specific groups), requirements to deploy police and security personnel, and duties to take steps to protect individuals from the actions of other individuals. These should be contrasted with negative obligations that, simply, require States to abstain from undue interference with the rights granted to individuals by the law.

Of course, in practice, the line dividing negative from positive obligations is not so clear, ${ }^{10}$ and, thus, it is not surprising that the EU institutions do not explicitly draw any distinction between the two while the ECtHR in its rulings does draw a distinction, albeit only when it is obvious which type of obligation is involved in the particular case. ${ }^{11}$ As the latter court has noted in, inter alia, Keegan v. Ireland,

the boundaries between the State's positive and negative obligations ... do not lend themselves to precise definition. The applicable principles are, none the less, similar. In both contexts regard must be had to the fair balance that has to be struck between the competing interests of the individual and of the community as a whole; and in both contexts the State enjoys a certain margin of appreciation. ${ }^{12}$

In this article, there will be no a priori, academic, discussion of whether the various rights that are discussed here impose, indeed, positive obligations (as is argued), nor will there be an effort to convince the reader that this is the case. This is for the simple, practical reason that doing so would be a gigantic task that would be worthy of a monograph in its own right and, thus, a journal article is not a suitable place to engage in this exercise. ${ }^{13}$ Moreover, this would be an unnecessary exercise given that - in the author's view - it is quite clear that the chosen obligations are, indeed, positive ones, not least because for many of them this has been explicitly acknowledged by judges and/or other scholars, as will be seen when these will subsequently be analysed.

Following this introduction, the article will proceed to explore how far, first, the ECHR (Section 2.1), and, second, EU law (Section 2.2), impose upon States positive obligations towards sexual minorities. The analysis will then proceed to consider whether more such obligations should be imposed by European law (Section 3) - in other words, what are the gaps that European law

10. Ibid., at 206

11. Orlandi and Others v. Italy, nos. 26431/12, 26742/12, 44057/12 and 60088/12, 14 December 2017, para. 198

12. Keegan v. Ireland, no. 16969/90, 26 May 1994, para. 49; this was confirmed more recently in, inter alia, Orlandi and Others v. Italy, ibid., para. 197. For an analysis of the argument that the court hearing a case should apply the same proportionality principles when deciding positive obligations as when deciding whether there has been a breach of a negative obligation, see Pitkänen, above n. 6

13. By way of indication, one article that (convincingly) argues that the right to marry (which is one of the rights mentioned in this article) derives from a positive obligation runs more than 70 pages! See G. Strauss, 'The Positive Right to Marry', 102 Virginia Law Review 1691 (2016). 
should fill in by imposing additional positive obligations towards sexual minorities? The section will, also, explore the possible reasons behind the reluctance on the part of the EU and the ECtHR to impose additional such obligations. Section 4 will analyse the argument that European law should not wait for hearts and minds to change before it imposes more positive obligations but rather that it should impose positive obligations exactly in order to contribute to changing hearts and minds. Section 5 will then conclude.

\section{Positive Obligations Towards Sexual Minorities Under European Law: The Current Position}

This section will aim to present the positive obligations towards sexual minorities that have already been imposed on European States by the ECHR and by EU law.

\subsection{Positive Obligations Towards Sexual Minorities Under the ECHR: The Current Position}

The ECHR is a regional human rights Treaty that was drafted by the Council of Europe in 1949, signed by the original ten member states in 1950 and entered into force in $1953 .{ }^{14}$ To ensure the observance of the obligations imposed on the contracting States, the Convention created two part-time institutions, the European Commission of Human Rights and the ECtHR. However, in 1998, with the coming into force of Protocol 11, the Commission was abolished, and the two old institutions were replaced by a full-time Court. The Convention focuses primarily on civil and political rights, which, at first glance, seems to be the reason that it is often read as a Treaty that imposes mainly negative obligations.

In the remainder of this part of the section, we shall focus on the various positive obligations that the ECtHR has expressly imposed on signatory states in situations involving sexual minorities. The ECtHR has not determined any general theory of positive obligations under the ECHR, ${ }^{15}$ but it has been noted that the theoretical basis for imposing such obligations is the combined effect of three, interrelated, principles:

1) First, the principle that, under article 1 of the Convention, states should secure Convention rights to everyone within their jurisdiction. 2) Second, the

14. For a detailed explanation of the ECHR, see E. Bates, The Evolution of the European Convention on Human Rights: From its Inception to the Creation of a Permanent Court of Human Rights (OUP, 2010); B. Rainey, P. McCormick, \& C. Ovey, Jacobs, White and Ovey: The European Convention on Human Rights (OUP, 2020); D. Harris, M. O'Boyle, E. Bates \& C. Buckley, Harris, O'Boyle and Warbrick: Law of the European Convention on Human Rights (OUP, 2018).

15. Harris, O'Boyle, Bates, \& Buckley, above n. 14, at 342. principle that the Convention rights so secured must be practical and effective not "theoretical and illusory". 3) Third, the principle that, under article 13, effective remedies should be provided for arguable breaches of Convention rights. ${ }^{16}$

\subsubsection{Positive Obligation to Protect LGB Persons Who Are Exercising Their Right to Freedom of Assembly and Association from the Hostile Acts of Other Individuals}

As Johnson has explained, when it comes to gay pride marches, Article $11 \mathrm{ECHR}$ - which provides to everyone the right to freedom of assembly and associationcan be breached as a result of a violation of both negative and positive obligations by signatory states:

First, there are the direct interferences by public authorities with demonstrations in the form of actions designed to disrupt them or prevent them from taking place. Second, where such events do take place, public authorities often fail to meet their positive obligations to ensure the protection of participants from counter-demonstrations. ${ }^{17}$

Similarly, emphasising the positive obligations that emerge in such situations, the Council of Europe has suggested that

Member States should ensure that law enforcement authorities take appropriate measures to protect participants in peaceful demonstrations in favour of the human rights of lesbian, gay, bisexual and transgender persons from any attempts to unlawfully disrupt or inhibit the effective enjoyment of their right to freedom of expression and peaceful assembly. ${ }^{18}$

The Court's approach in its case law does not diverge from the foregoing suggestions. The applicants in Identoba and others v. Georgia ${ }^{19}$ were the eponymous applicant (Identoba - a Georgian LGBT NGO) and a number of LGB individuals claiming that the violence perpetrated against them by private individuals and the lack of police protection during a peaceful march to mark the International Day Against Homophobia constituted a breach of their rights under a number of ECHR provisions. The ECtHR held that there was a violation of Article 3 ECHR (which prohibits torture and inhuman or degrading treatment or punishment) read in conjunction with Article 14 ECHR (which prohibits discrimi-

16. Starmer, above n. 9 , at. 194

17. P. Johnson, Homosexuality and the European Court of Human Rights (Routledge, 2014), at 184.

18. Council of Europe, 'Recommendation $C M / \operatorname{Rec}(2010) 5$ of the Committee of Ministers to Member States on Measures to Combat Discrimination on Grounds of Sexual Orientation or Gender Identity', para. 15.

19. Identoba and Others v. Georgia, no. 73235/12, 12 August 2015. For comments see P. Dunne, 'Enhancing Sexual Orientation and GenderIdentity Protections in Strasbourg', 75 Cambridge Law Journal 4 (2016). 
nation on a number of grounds in the enjoyment of the rights laid down in the ECHR): ${ }^{20}$

Given that they were surrounded by an angry mob that outnumbered them and was uttering death threats and randomly resorting to physical assaults, demonstrating the reality of the threats, and that a clearly distinguishable homophobic bias played the role of an aggravating factor, the situation was already one of intense fear and anxiety. The aim of the verbal - and sporadically physical - abuse was evidently to frighten the applicants so that they would desist from their public expression of support for the LGBT community. The applicants' feelings of emotional distress must have been exacerbated by the fact that the police protection which had been promised to them in advance of the march was not provided in due time or adequately. ${ }^{21}$

Accordingly, the Court concluded that the failure of the State to protect the demonstrators was considered degrading as it aroused in its targets feelings of fear, anguish and inferiority capable of humiliating and debasing them. It was noted that

[h]aving regard to the reports of negative attitudes towards sexual minorities in some parts of the society, as well as the fact that the organiser of the march specifically warned the police about the likelihood of abuse, the law-enforcement authorities were under a compelling positive obligation to protect the demonstrators, including the applicants, which they failed to do ....22

The Court also held that the disruption of the applicants' participation in the peaceful march - and the failure of the State to stop this, despite the fact that it had prior notice about the organisation of the march amounted to a breach of the State's positive obligations under Article 11 ECHR (which protects the right to freedom of assembly and association) taken in conjunction with Article 14 ECHR. The Court pointed out that

pluralism and democracy are built on genuine recognition of, and respect for, diversity. The harmonious interaction of persons and groups with varied identities is essential for achieving social cohesion. Referring to the hallmarks of a "democratic society", the Court has attached particular importance to pluralism, tolerance and broad-mindedness. In that context, it has held that although individual interests must on occasion be subordinated to those of a group, democracy does not simply mean that the views of the majority must always prevail: a balance must be achieved which ensures the fair and proper treatment

20. See, also, M.C. and A.C. v. Romania, no. 12060/12, 12 April 2016

21. Identoba and Others v. Georgia, above n. 19, para. 70.

22. Ibid., para. 80 . of minorities and avoids any abuse of a dominant position. $^{23}$

\section{The ECtHR then also noted that}

[t]he State must act as the ultimate guarantor of the principles of pluralism, tolerance and broadmindedness. Genuine, effective freedom of peaceful assembly cannot, therefore, be reduced to a mere duty on the part of the State not to interfere: a purely negative conception would not be compatible with the object and purpose of Article 11 of the Convention. This provision sometimes requires positive measures to be taken even in the sphere of relations between individuals, if need be. That positive obligation is of particular importance for persons holding unpopular views or belonging to minorities, because they are more vulnerable to victimisation. ${ }^{24}$

Accordingly, the ECtHR, in this ruling, made it clear that States must act to protect the right of the members of sexual minorities to hold a peaceful demonstration, not despite the fact that they may hold unpopular views that meet with disapproval by the majority, but, exactly, because - due to the majority's disapproval - they may be more vulnerable to victimisation. Hence, ECHR signatory states have the positive obligation to protect LGB persons who are exercising their right to peaceful assembly and association from the hostile acts of others.

\subsubsection{Positive Obligation to Protect LGB Persons from Homophobic Speech}

The Council of Europe has confirmed that homophobic speech is covered by the term 'hate speech', 25 and the ECtHR has held that concrete expressions constituting hate speech, which may be insulting to particular individuals or groups, are not protected by Article 10 ECHR (which provides the right to freedom of expression) and, thus, signatory states may be allowed to prohibit them. ${ }^{26}$

In the recent case of Beizaras and Levickas v. Lithuania ${ }^{27}$ the Court held that Article 8 ECHR (which provides for the right to private and family life), read in conjunction with Article 14 ECHR, imposes a positive obligation on signatory states to protect individuals from hate speech by other individuals. In particular, in this case the ECtHR held that Lithuania was in breach of the foregoing provisions as a result of failing to fulfil its positive obligation to LGB individuals to effectively investigate, prosecute and punish homophobic hate speech, which took the form of homophobic comments and threats made on a picture depicting a same-sex cou-

23. Ibid., para. 93

24. Ibid., para. 94

25. A. Weber, Manual on Hate Speech, Strasbourg (Council of Europe Publishing, 2009).

26. Jersild v. Denmark, no. 15890/89, 23 September 1994, para. 35. For a case that involved homophobic speech that the signatory state used as its defence in limiting the right to freedom of expression, see Vejdeland and Others v. Sweden, no. 1813/07, 9 February 2012.

27. Beizaras and Levickas v. Lithuania, no. 41288/15, 14 January 2020. 
ple kissing, which was posted (as a public post) on Facebook by the couple.

\section{The Court noted that}

the hateful comments including undisguised calls for violence by private individuals directed against the applicants and the homosexual community in general were instigated by a bigoted attitude towards that community and, secondly, that the very same discriminatory state of mind was at the core of the failure on the part of the relevant public authorities to discharge their positive obligation to investigate in an effective manner whether those comments regarding the applicants' sexual orientation constituted incitement to hatred and violence, which confirmed that by downgrading the danger of such comments the authorities at least tolerated such comments. ${ }^{28}$

As noted by another commentator, in this case

[t]he Court once again stressed that arguments based on the preferences of an (intolerant) majority in a society are not sufficient and have not been sufficient for a long time already. ${ }^{29}$

Accordingly, States must take positive steps to protect the rights of sexual minorities from the prejudiced majority as the (intolerant) hearts and minds of the majority cannot be used as an excuse for a failure (or, even worse, refusal) to act. For this reason, they have a positive obligation to protect LGB persons from homophobic speech.

\subsubsection{Positive Obligation to Put in Place a Legal Framemork for the Legal Recognition of Same-Sex Relationships}

The first step towards imposing a positive obligation on signatory states to make provision in their legal system for the legal recognition of same-sex relationships came in 2013, with the case of Vallianatos v. Greece. ${ }^{30}$ In this case the ECtHR held that if a contracting State makes available a system of registered partnerships as an 'alternative to marriage', Article $8 \mathrm{ECHR}$, read in conjunction with Article $14 \mathrm{ECHR}$, requires it to extend this status also to same-sex couples. Subsequently, the Court went further in the Oliari v. Italy case, ${ }^{31}$ where it held that Article 8 ECHR imposes a positive obligation to ensure respect for LGB persons' right to private and family life through the provision of a legal framework allowing them to have their relationship recognised and protected under domestic law. Nonetheless, as submit-

28. Ibid., para. 129

29. I. Milkaite, 'A Picture of a Same-Sex Kiss on Facebook Wreaks Havoc: Beizaras and Levickas v. Lithuania', Strasbourg Observers, 7 February 2020, https://strasbourgobservers.com/2020/02/07/a-picture-of-asame-sex-kiss-on-facebook-wreaks-havoc-beizaras-and-levickas-vlithuania/ (last visited 7 February 2020).

30. Vallianatos and Others v. Greece, nos 29381/09 and 32684/09, 7 November 2013.

31. Oliari and Others v. Italy, nos. 18766/11 and 36030/11, 21 July 2015. ted by others, ${ }^{32}$ the ruling seems to have imposed this obligation only on Italy, since the ECtHR in its judgment emphasised that the particular legal and social context in that signatory state seemed to require this. ${ }^{33}$ As Fenwick and Fenwick have stressed, in this case the ECtHR

identified two localised factors in particular that influenced its findings as to those requirements. The first comprised the "conflict between the social reality of the applicants, who for the most part live their relationship openly in Italy, and the law, which gives them no official recognition". The second concerned the "unheeded" calls of the Italian courts to introduce a legal framework providing same-sex couples with such recognition. ${ }^{34}$

More recently, in Orlandi v. Italy, ${ }^{35}$ the ECtHR imposed on signatory states a positive obligation deriving from Article $8 \mathrm{ECHR}$ to provide some means of recognition (i.e. not necessarily as 'marriages') to same-sex marriages contracted in other jurisdictions when these are sought to be registered in their territory.

Nonetheless, being unwilling 'to disturb the privileged status often afforded to married couples', 36 the Court has - to date - refused to impose a positive obligation on the contracting parties to extend marriage to same-sex couples. In Schalk and Kopf v. Austria, it held that Article 12 ECHR (which provides the right to marry) and Article $8 \mathrm{ECHR}$, read in conjunction with Article 14 ECHR, do not impose the positive obligation on signatory states to introduce same-sex marriage. ${ }^{37}$ As regards Article $12 \mathrm{ECHR}$, the ECtHR noted that at the time,

32. P. Dunne, 'Who Is a Parent and Who Is a Child in a Same-Sex FamilyLegislative and Judicial Issues for LGBT Families Post-Separation, Part I: The European Perspective', 30 Journal of the American Academy of Matrimonial Lawyers 27, at 29-30 and 36-37 (2017); S. Ragone and V. Volpe, 'An Emerging Right to a "Gay" Family Life? The Case of Oliari v. Italy in a Comparative Perspective', 17 German Law Journal 451, at 481 (2016); J. Mulder, 'Dignity or Discrimination: What Paves the Road Towards Equal Recognition of Same-Sex Couples in Europe?'. University of Bristol Law School Blog, 26 March 2018, https:// legalresearch.blogs.bris.ac.uk/2018/03/dignity-or-discrimination-whatpaves-the-road-towards-equal-recognition-of-same-sex-couples-ineurope/ (last visited 25 January 2020). In his Concurring Opinion in Oliari, in which he was joined by Judges Tsotsoria and Vehabovic, Judge Mahoney noted - referring to the other judges -'Our colleagues are careful to limit their finding of the existence of a positive obligation to Italy and to ground their conclusion on a combination of factors not necessarily found in other Contracting States' - Concurring Opinion in Oliari, above n. 31, by Judge Mahoney joined by Judges Tsotsoria and Vehabovic, para. 10.

33. Oliari, above n. 31, para. 181

34. H. Fenwick and D. Fenwick, 'Finding "East" /"West" Divisions in Council of Europe States on Treatment of Sexual Minorities: The Response of the Strasbourg Court and the Role of Consensus Analysis', 3 European Human Rights Law Review 247, at 264 (2019). See, also, H. Fenwick, 'Same Sex Unions at the Strasbourg Court in a Divided Europe: Driving Forward Reform or Protecting the Court's Authority Via Consensus Analysis?', 3 European Human Rights Law Review 248, at 262 (2016).

35. Starmer, above n. 10.

36. Johnson, above n. 17, at xii.

37. Schalk and Kopf v. Austria, no. 30141/04, 24 June 2010. This was subsequently confirmed in Chapin and Charpentier, no. 40183/17, 9 September 2016 and Orlandi, above n. 11. 
there was no European consensus regarding same-sex marriage, ${ }^{38}$ and thus it should 'not rush to substitute its own judgment in place of that of the national authorities, who are best placed to assess and respond to the needs of society'. ${ }^{39}$ From this, it followed that the obligation to open marriage to same-sex couples did not arise from Article $8 \mathrm{ECHR}$ read in conjunction with Article 14 ECHR either, as 'the Convention is to be read as a whole and its Articles should therefore be construed in harmony with one another'. ${ }^{40}$

Accordingly, at present, as long as one method of formalisation of same-sex unions is made available, the state's positive obligations under Article $12 \mathrm{ECHR}$ and Article 8 ECHR read alone or with Article 14 ECHR are likely to be found to be fulfilled, and the fact that samesex couples are not allowed access to marriage on grounds of their sexual orientation is not deemed to be discriminatory, even where there are significant differences between marriage and the other status(es) available to same-sex couples. ${ }^{41}$ When it comes to the issue of marriage equality, therefore, the ECtHR seems to have adopted a more cautious approach, indicating that it prefers to step back and wait for hearts and minds (and, for the majority of States' laws) to change before it interprets the ECHR as imposing on all signatory states a positive obligation to open marriage to same-sex couples.

\subsubsection{Positive Obligation to Extend the Right to Adopt to Single LGB Persons and to Same-Sex Couples If this is Available to Single Heterosexual Persons and to Unmarried Opposite-Sex Couples}

The same, cautious, approach, has been adopted by the Court in the context of parenting rights. In E.B. v. France, ${ }^{42}$ the ECtHR made it clear that Article 8 ECHR read in conjunction with Article 14 ECHR requires that if a signatory state grants the right to adopt to single persons, LGB single persons should also enjoy this right and, thus, should not be refused the right to adopt simply on the basis of their sexual orientation. Similarly, in $X$ and Others v. Austria, ${ }^{43}$ the Court held that the same provisions require that the (unmarried) same-sex partner of a woman is granted the right to apply for stepparent adoption of the latter's child, if such a right is granted to the (unmarried) opposite-sex partner of a heterosexual person. Nonetheless, in Gas and Dubois v.

41. H. Fenwick and A. Hayward, 'Rejecting Asymmetry of Access to Formal Relationship Statuses for Same and Different-Sex Couples at Strasbourg and Domestically', 6 European Human Rights Law Review 544, at 552 (2017). As the ECtHR noted in Schalk and Kopf v. Austria, above n. 36, para. 108,'the applicants appear to argue that if a State chooses to provide same-sex couples with an alternative means of recognition, it is obliged to confer a status on them which - though carrying a different name - corresponds to marriage in each and every respect. The Court is not convinced by that argument. It considers on the contrary that States enjoy a certain margin of appreciation as regards the exact status conferred by alternative means of recognition'.

42. E.B. v. France, no. 43546/02, 22 January 2008.

43. $X$ and Others v. Austria, no. 19010/07, 19 February 2013.
France, ${ }^{44}$ it was held that if a signatory state makes available step-parent adoption only to married couples (and in that signatory state only opposite-sex couples can marry), then it is not obliged by the ECHR to make step-parent adoption available to same-sex couples, in this way allowing signatory states to maintain the distinction between married couples and unmarried couples - by maintaining a preferential status for married couples - and to discriminate against same-sex couples in the context of parenting.

\subsubsection{Positive Obligation to Extend Family Reunification} Rights to Same-Sex Couples

In Pajic v. Croatia, ${ }^{45}$ the ECtHR held that Article 8 ECHR, read in conjunction with Article 14 ECHR, requires signatory states that grant family reunification rights to unmarried, opposite-sex couples to extend these in the same way to unmarried same-sex couples.

Moreover - and going one step further - in Taddeucci and $M c$ Call v. Italy, ${ }^{46}$ the Court departed from its usual approach of maintaining a separate - preferential - status for married couples, which justifies better treatment being reserved for them and which (in States which have not introduced same-sex marriage) justifies discrimination against same-sex couples who are legally incapable of contracting a marriage. In this case, Italy did not grant a residence permit on family reunification grounds to unmarried partners (whether they were in an opposite-sex or same-sex relationship). The Court held that this amounted to a violation of Article 14 ECHR, read together with Article $8 \mathrm{ECHR}$, in cases involving unmarried same-sex couples, as the latter were not similarly situated with unmarried opposite-sex couples, in that same-sex couples did not have the option of marrying or, at the relevant time, of obtaining any other form of legal recognition of their situation in Italy. Accordingly, the Court found that same-sex unmarried couples should not be treated in the same way as opposite-sex unmarried couples, as Italy should have taken into account - when defining 'family members' for the purposes of family reunification - that same-sex couples could under no circumstances formalise their relationship in its territory. Hence, signatory states that have not introduced same-sex marriage in their territory have the positive obligation to extend the same family reunification rights they grant to married couples to unmarried same-sex couples.

The different outcome in Taddeucci and McCall v. Italy, on the one hand, and Gas and Dubois v. France (seen in the previous sub-section), on the other, can be attributed to the difference in 'sensitivity' of the matters that were involved: Gas and Dubois involved the parenting rights of same-sex couples, which is a very controversial area, ${ }^{47}$ whereas Taddeucci and $M c$ Call involved the family reunification rights of a same-sex couple: the latter,

\footnotetext{
44. Gas and Dubois v. France, no. 25951/07, 15 March 2012.

45. Pajic v. Croatia, no. 68453/13, 23 February 2016.

46. Taddeucci and McCall v. Italy, no. 51362/09, 30 June 2016.

47. Dunne (2017), above n. 32, at 31 (and the references in footnote 13 of that article).
} 
though, indeed, a rather sensitive area that touches on national immigration policies, is nowhere near as controversial as the parenting rights of same-sex couples or the requirement to introduce same-sex marriage. Accordingly, in this area the Court feels confident to proceed and impose positive obligations, namely, to extend family reunification rights to same-sex couples, without waiting, first, for hearts and minds to change.

\subsection{Positive Obligations Towards Sexual Minorities Under EU Law: The Current Position}

As explained earlier, the ECHR is a regional human rights Treaty that aims to impose human rights obligations on its signatory states that are given effect by the rulings of the ECtHR. The EU, on the other hand, comprises a more complex framework: not only does it impose obligations on its Member States in a number of different areas, but its Member States have limited their sovereign rights in specific fields and have given competence to the EU to take (legislative or other) action in those fields. Accordingly, unlike the ECHR, which only imposes obligations on its signatory states, the obligations arising from EU law are imposed at two different levels: the EU level (on the EU itself and, in particular, on its institutions) and the national level (on the EU Member States).

In the last couple of decades, the EU has taken some steps towards the protection of the rights of sexual minorities, although these have mostly been aimed at eradicating discrimination based on sexual orientation rather than imposing specific, positive obligations on the EU institutions or the Member States. ${ }^{48}$

At the EU level, the EU Staff Regulations impose on EU institutions the negative obligation not to discriminate against their employees on the basis of their sexual orientation. ${ }^{49}$ In addition, the EU Charter of Fundamental Rights (EUCFR) ${ }^{50}$ which, according to its Article 51 , is 'addressed to the institutions, bodies, offices and agencies of the Union', prohibits 'any discrimination' based on a number of grounds, which include sexual orientation, ${ }^{51}$ in this way imposing a general negative obligation on the EU institutions not to discriminate on the grounds of sexual orientation when exercising their powers. The aim of combating discrimination on the grounds of sexual orientation is, however, also, embodied in the positive obligation imposed on the EU institutions by Article 10 of the Treaty on the Functioning of the European Union (TFEU), which is a main-

48. A. Tryfonidou, 'Law and Sexual Minority Rights: Navigating a Political Minefield', in P.J. Cardwell and M.-P. Granger (eds.), Research Handbook on the Politics of EU Law (Edward Elgar, 2020).

49. See Arts. $1 d$ and 26 of Regulation No 31 (EEC), 11 (EAEC), laying down the Staff Regulations of Officials and the Conditions of Employment of Other Servants of the European Economic Community and the European Atomic Energy Community [1962] OJ P45/1385 (as amended), https://eur-lex.europa.eu/legal-content/EN/TXT/?uri=CELEX \%3A01962R0031-20140501 (last visited 7 January 2020). See, also, F-86/09 W v. European Commission ECLI:EU:F:2010:125.

50. Charter of Fundamental Rights of the European Union, [2012] O] C326/391.

51. Art. 21 EUCFR. streaming provision (and, as such, unenforceable before a court) that requires that

[i]n defining and implementing its policies and activities, the Union shall aim to combat discrimination based on sex, racial or ethnic origin, religion or belief disability, age or sexual orientation.

Despite the fact that this positive obligation is an important reminder that - at least on paper - discrimination against sexual minorities cannot be tolerated in the context of any of the EU's policies, in reality, there has been no examination of whether the EU, indeed, takes this seriously when it engages in policy-making or other activities.

As regards the national level, EU law imposes some more concrete legal obligations towards sexual minorities on its Member States. Given that the EUCFR binds, also, Member States 'when they are implementing Union law', 52 the negative obligation not to discriminate on the grounds of sexual orientation laid down in Article 21 EUCFR is, also, imposed on Member States in situations that fall within the scope of EU law. ${ }^{53}$

And although the constituent EU Treaties do not impose any explicit positive obligations on EU Member States towards sexual minorities, a number of such obligations have been imposed by secondary EU legislation. The first instrument that was introduced for this purpose is Directive $2000 / 78,{ }^{54}$ which requires EU Member States to prohibit within their legal system discrimination on a number of grounds, including discrimination based on sexual orientation. The Directive has a limited material scope - it requires Member States to prohibit discrimination on the relevant grounds only in the area of employment and occupation - which is why there have been calls for the promulgation of another Directive that would prohibit discrimination on the same grounds but outside the context of employment. ${ }^{55}$ The 2000 Directive imposes a positive obligation as its aim is to require Member States to protect individuals as employees - from being discriminated against on a number of grounds (including sexual orientation) by their employer. The Directive does not, merely, require Member States to introduce legislation that prohibits discrimination on the above grounds in the area of

52. Art. 51 EUCFR.

53. For a case involving this, see Léger, above $\mathrm{n} .4$.

54. Directive $2000 / 78$, OJ 2000 L 180/22. For an analysis of the prohibition of discrimination on the grounds of sexual orientation under the Directive, see A. Tryfonidou, 'The Impact of the Framework Equality Directive on the Protection of LGB Persons and Same-Sex Couples from Discrimination under EU Law', in U. Belavusau and K. Henrard (eds.), EU Anti-Discrimination Law Beyond Gender (Hart, 2018).

55. Commission, 'Proposal for a Council Directive Implementing the Principle of Equal Treatment between Persons Irrespective of Religion or Belief, Disability, Age or Sexual Orientation', (2008) COM 426 final (currently in legal limbo as the required unanimity in Council has failed to be achieved). This was accompanied by a Communication from the Commission to the European Parliament, the Council, the European Economic and Social Committee and the Committee of the Regions 'Non-Discrimination and Equal Opportunities: A Renewed Commitment', (2008) COM 420. 
employment and occupation, but also to prohibit harassment that is based on the above grounds, as well as to ensure that judicial and/or administrative procedures for the enforcement of obligations under the Directive are available to all persons whose rights under this instrument have been violated. ${ }^{56}$ The Directive - and, in particular, the requirement to prohibit discrimination on the grounds of sexual orientation - has been interpreted by the Court of Justice in a number of cases. However, through these rulings the Court has merely offered a clarification as to how the prohibition of discrimination on the grounds of sexual orientation should be interpreted ${ }^{57}$ or regarding the temporal scope of application of the Directive, ${ }^{58}$ without imposing any additional positive obligations on EU Member States.

Directive 2000/78 is the only EU legal instrument that expressly imposes a positive obligation on Member States aiming to protect the rights of sexual minorities. Nonetheless, this has not prevented the CJEU from deriving from other legal instruments, which are not specifically concerned with the rights of sexual minorities, positive obligations in order to guarantee the protection of the rights of the latter. In the remainder of this section, two such instruments will be considered: Directive 2004/38 and Directive 2011/95.

Directive 2004/3859 elaborates the rights to free movement and residence that Union citizens and - through them - their family members enjoy under EU law. This instrument is not concerned, specifically, with the rights of sexual minorities, though its recital 31 provides that Member States should implement this Directive without discrimination between its beneficiaries on, inter alia, grounds of sexual orientation. Obviously, the rights laid down in the EU free movement of persons provisions in the TFEU and in this Directive are enjoyed by all Union citizens, irrespective of sexual orientation; thus LGB Union citizens should enjoy the rights to move and reside freely in the Member State of their choice in the same way that heterosexual Union citizens do.

Recognising the importance of family life and the need to ensure that Union citizens can continue the family life they established in one Member State after their movement to another Member State, the 2004 Directive grants so-called 'family reunification rights' to Union citizens: it provides that Union citizens who move to a Member State other than that of their nationality can be joined or accompanied in that Member State by their close family members (irrespective of the family member's nationality). According to Article 2(2) of the Directive, one of the categories of family members in respect of whom the Union citizen can claim family

56. Art. 9 of Directive 2000/78, above n. 54 .

57. See, for instance, Case C-267/06 Maruko EU:2008:179; Case C-147/08 Römer EU:C:2011:286; Case C-267/12 Hay ECLI:EU:C: 2013:823; Case C-81/12 Asociaţia Accept EU:C:2013:275; Case C-507/18 NH v. Associazione Avvocatura per i diritti LGBTI - Rete Lenford EU:C:2020:289.

58. Case C-258/17 E.B. ECLI:EU:C:2019:17.

59. Directive 2004/38, OJ 2004 L 158/77. reunification rights is the spouse of the Union citizen. The CJEU was recently confronted with the question of whether the term 'spouse', for the purposes of the Directive, should be read as including the same-sex spouse of a Union citizen who exercises free movement rights. In Coman, ${ }^{60}$ the Court answered this question affirmatively, in this way imposing a positive obligation on EU Member States to recognise the same-sex marriages of Union citizens for the purpose of the grant of family reunification rights when they exercise their free movement rights under EU lam. As explained elsewhere, ${ }^{61}$ the ruling does not impose a general positive obligation on EU Member States to introduce same-sex marriage in their territory, nor does it even impose an obligation to recognise the same-sex marriages that Union citizens who move to their territory contracted elsewhere, for all legal purposes: it simply imposes on EU Member States the positive obligation to accept within their territory the same-sex spouse of a Union citizen, and the Court's rationale for doing this is a purely functional one, seeking to ensure that (LGB) Union citizens will not be deterred from exercising their free movement rights, rather than a genuine wish to protect the rights of sexual minorities.

The second EU legislative instrument that imposes positive obligations on EU Member States, which in certain cases can (positively) affect the position of LGB persons, is Directive 2011/95. ${ }^{62}$ As a result of the powers granted to the EU by the Treaty of Amsterdam in 1999 in the areas of asylum and immigration, ${ }^{63}$ the EU drafted legislation laying down minimum standards with which EU Member States must comply when determining whether a third-country national or a stateless person is a refugee. The first such instrument was Directive 2004/83, ${ }^{64}$ which has been repealed and replaced by the currently applicable legislation, Directive 2011/95. ${ }^{65}$ The latter instrument, like its predecessor, imposes a set of positive obligations on Member States with regard to asylum seekers. Most important for our purposes is Article 10 of the 2011 Directive, which provides that persons who seek asylum on the ground that they cannot return to their country of origin because they are in danger of being persecuted as a result of their sexual orientation can qualify as 'members of a particular social group' and, thus, as refugees, for the purposes of the Directive. Accordingly, EU Member States are under a positive obligation to provide asylum to LGB persons who satisfy the requirements laid down in the above instrument. ${ }^{66}$

60. Case C-673/16, Coman EU:C:2018:385.

61. A. Tryfonidou, 'The ECJ Recognises the Right of Same-Sex Spouses to Move Freely between EU Member States: The Coman Ruling', 44 European Law Review 662 (2019).

62. Directive 2011/95/EU, OJ 2011 L 337/9.

63. These are now found in Title $\mathrm{V}$, Chapter 2 TFEU.

64. Council Directive 2004/83, OJ 2004 L 304/12 (repealed).

65. Above n. 62

66. The CJEU has been given the opportunity to analyse these requirements in three cases that were referred to it for a preliminary ruling: Joined Cases C-199-201/12 X, Y and Z ECLI:EU:C:2013:720; C-148-150/13 $A, B$ and C EU:C:2014:2406; C-473/16 F EU:C:2018:36. Owing to the 


\section{Should European Law} Impose On European States Additional Positive Obligations Towards Sexual Minorities?

Although, as seen in the previous section, the EU and the ECtHR have imposed certain positive obligations towards sexual minorities, and although these are a good starting point on the road to substantive equality for sexual minorities, there is clearly scope for additional such obligations. This section will have a twofold aim: to consider the reasons behind the EU's and the ECtHR's reticence in imposing additional positive obligations towards sexual minorities and to suggest which such additional obligations should be imposed by European law.

\subsection{Should the ECHR Impose on Signatory States More Positive Obligations Towards Sexual Minorities?}

The ECHR and, in particular, the ECtHR as the interpreter of the former, have often been castigated for not doing enough for protecting LGB rights. However, when assessing the impact of the ECHR on the protection of LGB rights, it is important to remember the setting in which it is operating, which can, clearly, explain the ECtHR's reticence in many instances to impose additional obligations - especially positive obligations that can be perceived as more interventionist, as they require the signatory states to take positive measures to protect LGB persons or to introduce a legal framework that secures the extension of specific rights to sexual minorities.

Accordingly, in this first part of the sub-section, the possible reasons behind the imposition of only limited positive obligations towards sexual minorities by the ECtHR will be explored.

The first such reason is that the rights of sexual minorities constitute a sensitive and controversial area, which is closely intertwined with issues relating to religion, tradition, culture and morality. There is a clear divide in Europe with regard to matters touching on sexual minority rights, with some states being much more reluctant to recognise (m)any rights for LGB persons, often invoking the need to protect the family in the traditional sense and the traditional values and identity of the country. Accordingly, the ECtHR needs to be careful when selecting the steps it will take on the road that will lead to substantive equality for sexual minorities, in that those steps should be such as not to be greeted with hostility and resistance by the more 'backward' signatory States that are, often, reluctant to even accept that

technical - and specific - nature of these rulings, their analysis will not add anything to the argument made in this article and, thus, they will not be analysed here. the rights of sexual minorities are human rights, while ensuring that it gradually adds to the obligations that signatory states have towards sexual minorities. Therefore, the ECtHR seems to be choosing its battles by imposing obligations only when it feels that signatory states will be ready to accept them, in this way avoiding a direct conflict with some signatory states while ensuring that it will preserve its legitimacy as an authoritative Court whose judgments are not disregarded ${ }^{67}$

Secondly, it should be remembered that the ECtHR is a court of law and thus which obligations it imposes very much depend on what applications it receives and thus it is something that is done on an ad hoc and reactive manner rather than as part of an organised strategy on its part. ${ }^{68}$ Accordingly, certain positive obligations may not have been imposed by the ECtHR simply because it has not yet had the chance to do so.

Finally, the ECtHR's approach is that when a matter falls within the 'social strategy' of signatory states, the latter maintain a wide margin of appreciation with regard to them. ${ }^{69}$ Thus, because the issues concerning sexual minorities are considered to be such a matter, the ECtHR allows leeway to signatory states to exempt themselves from them. ${ }^{70}$ Nonetheless, quite interestingly, in its judgments the ECtHR has also recognised that particularly weighty reasons must be relied on for justifying discrimination on the grounds of sexual orientation, ${ }^{71}$ in this way making it uncertain how this can be reconciled with the wide margin of appreciation left to the signatory states in such instances. ${ }^{72}$ Fenwick and Fenwick have, in fact, sought to provide a logical explanation behind this inconsistency in the Court's approach: they explain that it all boils down to the question of whether the Court perceives there to be a consensus among the signatory states with regard to an issue: if so (e.g. in situations involving hate speech) then a narrow margin of appreciation is left to signatory states, and, thus, it is very difficult to justify a difference in treatment that disadvantages sexual minorities, whereas if the Court feels there is no consensus among the signatory states (e.g. same-sex marriage), then it leaves a wide margin of appreciation. ${ }^{73}$ Accordingly, and

67. See, inter alia, Fenwick and Fenwick, above n. 34; Fenwick, above n. 34, at 249; K. Henrard, 'How the ECtHR's Use of European Consensus Considerations Allows Legitimacy Concerns to Delimit its Mandate', in P. Kapotas and V. P. Tzevelekos (eds.), Building Consensus on European Consensus (CUP, 2019), at 159

68. Of course, many of the cases that reach the Court are part of strategic litigation by LGBT+ advocacy groups such as ILGA Europe, Stonewall, and NELFA, which is designed to elicit a Court ruling on a particular issue.

69. Gas and Dubois v. France, above n. 44, para. 60.

70. Johnson, above n. 17, at 136. For a defence of the margin of appreciation doctrine, see J.A. Sweeney, 'Margins of Appreciation: Cultural Relativity and the European Court of Human Rights in the Post-Cold War Era', 54 International and Comparative Law Quarterly 459 (2005).

71. Gas and Dubois v. France, above n. 44, para. 59.

72. For an analysis of the uncertainty that arises as a result of the relationship between consensus-based analysis and the margin of appreciation doctrine, see Fenwick, above n. 34, at 251-52.

73. Fenwick and Fenwick, above n. 34. For a similar argument with regard to the freedom of religion, see K. Henrard, 'How the European Court of Human Rights' Concern Regarding European Consensus Tempers the 
as seen in the previous section, the Court seems to have chosen to first impose on signatory states obligations towards sexual minorities in areas that are less controversial and in which a certain level of consensus has been reached, leaving the more 'difficult' issues to be tackled - if at all - at a later time.

Having considered the reasons that seem to be lying behind the ECtHR's perceived reticence to impose more positive obligations on signatory states in this context, the next question will be which additional positive obligations towards sexual minorities should be considered as deriving from the ECHR?

The first obligation that the ECtHR should impose is to extend the right to marry to same-sex couples. As we saw in the previous section, at the moment, the ECtHR merely requires (as a result of Oliari $^{74}$ ) signatory states to allow same-sex couples to formalise their relationship (without it being required to allow same-sex marriage), and this is only when their social and legal setting requires this. From the obligation to introduce same-sex marriage it would, also, follow that when a same-sex couple has contracted a marriage in another country, this should be recognised as a marriage in all signatory states (in this way building on Orlandi $i^{75}$ ), in situations where this is the case for opposite-sex couples: in other words, signatory States will only be able to refuse to recognise same-sex marriages contracted abroad on the same bases as they do for opposite-sex married couples and irrespective of mhether the marriage is between members of the same or opposite sex.

The fact that same-sex couples would have the option of contracting a marriage would, automatically, also mean that they would enjoy the same rights and benefits that opposite-sex (married) couples enjoy. In other words, the current division (which exists in some European States) between married couples and everyone else would no longer legitimately result in the automatic exclusion of same-sex couples from rights and benefits reserved for married couples, as same-sex couples would, now, be able to join the 'club' of married couples. For the foregoing developments, the Court would have to depart from its ruling in Schalk and Kopf v. Austria, where, as we saw, it held that currently there is no consensus among a sufficient number of signatory states on holding that there is a positive obligation under the ECHR to open marriage to same-sex couples. ${ }^{76}$

But what would be the rationale behind the introduction of the above obligations? If the ECtHR indeed recognises (as it does, given that it prohibits discrimination on the grounds of sexual orientation) that all persons - irrespective of sexual orientation - are of equal moral worth, and that LGB persons, like everyone else, should be able to freely exercise their choices for a good life, then it cannot be accepted that one of the fundamental human rights laid down in the ECHR - namely, the

Effective Protection of Freedom of Religion', 4 Oxford Journal of Law and Religion 398 (2015), at 415.

74. Oliari and Others v. Italy, above n. 31

75. Orlandi and Others v. Italy, above n. 11.

76. Schalk and Kopf v. Austria, above n. 37, para. 58. right to marry - can be refused to them simply because of their sexual orientation. Same-sex couples should not be subjected to the indignity of denial of public affirmation of their relationship and, more practically, to the denial of civil benefits that are otherwise available to couples that have chosen to formalise their relationship. Denial of access to a formalised relationship status on grounds of sexual orientation 'can also strongly reinforce a general cultural acceptance of homophobia, and furthers the notion that homophobia should be accorded legal recognition'. ${ }^{77}$ The right to human dignity has, in fact, been the basis for the extension, in other legal systems, of the right to marry to LGB persons and can, also, be used in the ECHR context for arguing that a positive obligation should be imposed on signatory states, not, merely, to enable same-sex couples to formalise their relationship but, more broadly, to marry. ${ }^{78}$

As explained by the Inter-American Court of Human Rights in its Advisory Opinion OC-24/17:

there would be no point in creating an institution that produces equal effects and gives rise to the same rights as marriage, but is not called marriage, except to draw attention to same-sex couples by the use of a label that indicates a stigmatising difference or that, at the very least, belittles them. On that basis, marriage would be reserved for those who, according to the stereotype of heteronormativity, were considered "normal", while another institution with identical effects but under a different name would exist for those who do not fit this stereotype. ${ }^{79}$

Accordingly, Article 12 ECHR should be read as granting the right to marry also to same-sex couples. Waiting for hearts, minds and the majority of national laws to change, before such an obligation is imposed, demonstrates that the ECtHR is not taking LGB equality seriously.

The same can be argued for the parenting rights of same-sex couples. As already seen in the previous section, another gap in the positive obligations imposed by the ECHR is in relation to parenting rights. At the moment, the ECtHR has made it clear that the ECHR does not impose specific positive obligations as to who can 'found a family' and under what circumstances. Accordingly, the signatory states can create their own framework determining who can become a de facto parent and who can be legally recognised as a parent, while the ECHR has not been read, for instance, as

77. Fenwick and Fenwick, above n. 34, at 261

78. P.J. Laverack, 'The Indignity of Exclusion: LGBT Rights, Human Dignity and the Living Tree of Human Rights', 2 European Human Rights Law Review 172 (2019).

79. Inter-American Court of Human Rights Advisory Opinion OC-24/17, 24 November 2017. Series A No. 24. Non-Official Brief, www.corteidh.or.cr/cf/Jurisprudencia2/overview.cfm? doc $=1884$ \&lang=en (last visited 17 February 2020). See, also, the US Supreme Court's judgment in Obergefell v. Hodges, 576 US (2015); and the Constitutional Court of South Africa judgment in Minister of Home Affairs v. Fourie, Lesbian and Gay Equality Project v. Minister of Home Affairs (2005) ZACC 19, www.saflii.org.za/za/cases/ZACC/ 2005/19.html (last visited 18 February 2020). 
imposing an obligation on signatory states to enable same-sex couples to become the de facto joint parents of a child and to be legally recognised as such. However,

a State which creates a right going beyond its obligations under Article 8 of the Convention may not apply that right in a manner which is discriminatory within the meaning of Article 14, ${ }^{80}$

which is the reason that in its case law the Court has found, for instance, that if single persons are allowed to adopt, then refusing to allow a single person to adopt simply on the grounds of his sexual orientation is not allowed. ${ }^{81}$ This rationale should be extended to situations where a signatory state that allows same-sex couples to enter into a registered partnership that is, also, available to opposite-sex couples, refuses the right to jointly parent a child to the former but not to the latter: ${ }^{82}$ in such instances, the ECtHR should hold that there is discrimination on the grounds of sexual orientation as regards the right to found a family that is contrary to Article $8 \mathrm{ECHR}$ read in conjunction with Article 14 ECHR.

On the other hand, as seen earlier, the Court continues to allow the signatory states to draw a distinction as to who can create a family and be recognised as a parent, which is based on marriage: if the choice of a signatory state is to allow only married couples to become parents and to be legally recognised as the joint parents of their child, and in that State same-sex couples cannot marry, this means that same-sex couples are automatically excluded from being legally recognised as the joint parents of their children. Accordingly, as it held in the case of Tadeucci and McCall v. Italy, ${ }^{83}$ the Court in this context should, also, find that a difference in treatment based on marriage in a signatory state that does not allow same-sex couples to marry amounts to discrimination on the grounds of sexual orientation. The ECtHR should, therefore, impose a positive obligation on signatory states that do not provide for same-sex marriage and do not allow unmarried couples to become the joint (legal) parents of a child, to nonetheless allow unmarried same-sex couples to become the joint (legal) parents of a child as, otherwise, they will be discriminated against on the grounds of their sexual orientation. The argument, in particular, is that in such cases unmarried same-sex couples are treated in the same way as unmarried opposite-sex couples, even though these two categories of couples are differently situated in that the latter can formalise their relationship by getting married, whereas the former do not have this option. ${ }^{84}$

80. $X$ and Others v. Austria, above n. 43, para. 135

81. See E.B. v. France, above n. 42.

82. This is, for instance, the position in Cyprus - see Civil Partnership Law

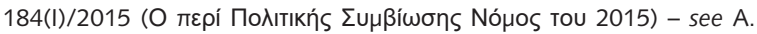
Tryfonidou, 'The Legal Position of LGBT Persons and Same-Sex Couples in Cyprus', 29 The Cyprus Review 183, at 208 (2018)

83. Tadeucci and McCall v. Italy, no. 51362/09, 30 June 2016, esp. paras. 82-86 and 94-95.

84. In Thlimmenos v. Greece, no. 34369/97, 6 April 2000, para. 44, the ECtHR held that discrimination in the ECHR context should be read as
As the Court noted in Taddeucci and McCall, in certain circumstances a failure to attempt to correct inequality through different treatment may in itself give rise to a breach' of Article 14 ECHR. ${ }^{85}$ Accordingly, when these differently situated categories of couples are treated in the same way, this should be found to amount to discrimination on the grounds of sexual orientation, and, hence, in practice, what is required is that if the signatory state reserves parenting rights for married couples and does not allow same-sex couples to marry, it should make an exception and allow unmarried same-sex couples to become the joint parents of a child. ${ }^{86}$

Finally, at the moment, homophobic treatment does not appear in itself to amount to a breach of any of the rights protected under the ECHR. However, as Johnson has suggested, it should be considered to amount to degrading treatment under Article 3 ECHR, and, thus, negative and positive obligations to this effect should be imposed. ${ }^{87}$ After all, discrimination based on race has been classified as degrading treatment contrary to Article $3 \mathrm{ECHR},{ }^{88}$ and, thus, there is no reason why this should not also be the case for discrimination based on sexual orientation. Moreover, the Court has, already, derived negative $\left(X\right.$ v. Turkey $\left.{ }^{89}\right)$ and positive (Identoba v. Georgia ${ }^{90}$ and M.C. and A.C. v. Romania ${ }^{91}$ ) obligations from Article $3 \mathrm{ECHR}$, in cases involving LGB persons.

As noted by Johnson and Falcetta,

art. 3 provides the means to develop Convention jurisprudence in ways that more holistically and comprehensively address sexual orientation discrimination in contemporary societies. ... Article 3 can, for example, be used as a framework for conceptualising how certain forms of discrimination on the grounds of sexual orientation diminishes the social status of sexual minorities, as both individuals and as a group, in ways that might incubate forms of ill-treatment against them. ${ }^{92}$

Accordingly, the ECtHR should read Article 3 ECHR as imposing on signatory states the positive obligation to protect LGB persons from homophobic treatment effected by other individuals. In this way it will send a strong

encompassing both differential treatment of categories of persons similarly situated and the same treatment of categories of persons differently situated.

85. Tadeucci and McCall, above n. 83, para. 81

86. To be pragmatic, it is, of course, recognised that given how controversial the parenting rights of same-sex couples are - which are, even, more controversial than the right of same-sex couples to marry - it is very unlikely that the ECtHR would any time soon impose such an obligation on signatory states.

87. Johnson, above n. 17, at 209. For a detailed analysis of this argument see P. Johnson and S. Falcetta, 'Sexual Orientation Discrimination and Article 3 of the European Convention on Human Rights: Developing the Protection of Sexual Minorities', 43 European Law Review 167 (2018).

88. Moldovan and Others v. Romania (No. 2), nos. $41138 / 98$ and 64320/01, 12 July 2005

89. X v. Turkey, no. 24626/09, 9 October 2012

90. Identoba and Others v. Georgia, above n. 19

91. M.C. and A.C. v. Romania, above n. 20.

92. Johnson and Falcetta, above n. 87, at 168. 
signal to everyone that homophobia cannot be tolerated under any circumstances. Such a move would, then, be expected to, initially, diminish the general feeling in certain societies that homophobia is acceptable or even as part of machismo culture - a necessary trait that must be demonstrated by 'real men'; and perhaps it might eventually lead to a change in hearts and minds.

\subsection{Should the EU Impose on Signatory States More Positive Obligations Towards Sexual Minorities?}

As argued elsewhere, ${ }^{93}$ there are a number of reasons why the EU institutions have been somewhat reticent in their approach towards protecting the rights of sexual minorities under EU law. Some of these reasons are very similar to those that have prevented the ECtHR from adopting a more coherent and expansive policy towards the protection of the rights of sexual minorities. Hence, like the ECtHR, the EU institutions are also choosing their battles by imposing obligations towards sexual minorities only when they feel that EU Member States will be ready to implement them.

A more pragmatic reason, nonetheless, why the EU institutions have not imposed - and are unlikely to impose - a long list of positive obligations towards sexual minorities on EU Member States is, simply, that the EU does not have the competence to act in the relevant areas. After all, unlike the ECHR, which is a human rights Treaty, the EU started off as mainly an economic organisation, and any human rights protection offered by it has been incidental to the achievement of its (mainly) economic objectives. The EU, therefore, does not have competence in the area of human rights, and thus the EU legislature cannot make legislation that simply aims to protect human rights. Nor can the EU take any action that aims to protect human rights if this is not in some way connected to its areas of competence or, at least, to situations that fall within the scope of EU law. ${ }^{94}$ Hence, the rights of sexual minorities under EU law are protected only when this is deemed necessary in order to ensure that the rights granted by it (such as free movement rights) are not violated or when this is deemed necessary for achieving the EU's objectives.

There is no doubt that the EU does not have the competence to impose a positive obligation on its Member States to open marriage or, even, registered partnerships to same-sex couples in their territory. This is not only a human rights issue with respect to which the EU does not have competence, but also an issue that falls within the area of family law, which, likewise, is an area that falls within exclusive Member State competence. Nonetheless, if the EU Member States' failure to allow or, even, recognise same-sex marriages and registered part-

93. Above n. 48.

94. These reasons have been cited by Wintemute as possible reasons behind the CJEU's less 'brave' approach in cases involving LGBT persons - see R. Wintemute, 'In Extending Human Rights, Which European Court is Substantively "Braver' and Procedurally "Fitter"?: The Example of Sexual Orientation and Gender Identity Discrimination', in S. Morano-Foadi and L. Vickers (eds.), Fundamental Rights in the EU: A Matter for Two Courts (Hart, 2015), at 192-94. nerships interferes with the enjoyment of rights deriving from EU law, then EU law can intervene by imposing specific positive obligations on the Member States. The clearest example of this is the Coman case seen in the previous section, ${ }^{95}$ where, in order to remove obstacles to free movement, the CJEU held that EU Member States are obliged to recognise same-sex marriages contracted in other EU Member States in situations that involve the exercise of EU free movement rights. However, in this case the CJEU - taking into account the sensitive nature of this matter and the possible negative reaction of some Member States to a ruling that would impose broader obligations - was careful to limit the effect of its judgment by noting that EU Member States are only required to recognise same-sex marriages contracted in an EU Member State, that they are required to recognise such marriages only for the purpose of determining the existence of family reunification rights deriving from EU law, and only in situations where an EU citizen moves with his/her same-sex spouse to that Member State with the aim of settling there. It is clear, nonetheless, that - even if such a purely functional (free movement-based) approach is taken - the obligation to recognise same-sex marriages contracted elsewhere should be imposed in a broader range of circumstances (in cases where the marriage was contracted outside the $\mathrm{EU}$; in cases involving temporary, short-term, movements between EU Member States; and for a wider range of legal purposes (i.e. not just for family reunification purposes)). The same (free movement) rationale can be used to require in all instances ${ }^{96}$ the cross-border legal recognition of same-sex relationships and, as argued elsewhere, ${ }^{97}$ more broadly, the cross-border legal recognition of the familial ties among the members of rainbow families.

Finally, in situations falling within the scope of EU law, the same, broad, approach to discrimination on the grounds of sexual orientation should be adopted, as has been followed towards discrimination on the grounds of nationality in the context of free movement and Union citizenship. In Garcia Avello, ${ }^{98}$ the CJEU noted that in situations where Union citizens who are nationals of two EU Member States and Union citizens who hold the nationality of only one EU Member State are not similarly situated for a specific purpose, the two categories of Union citizens must not be treated in the same way: if they are, this amounts to discrimination on the grounds of nationality and is contrary to EU law and, in particular, Article 20 TFEU (which provides that Union citizens shall enjoy the rights provided for in the EU Treaties) read in conjunction with Article 18 TFEU (which

95. Above n. 60

96. At the moment, Directive $2004 / 38$ only imposes an obligation on the host Member State to recognise registered partnerships (whether samesex or opposite-sex) if in its legislation it recognises them as equivalent to marriage - see Art. 2(2)(b) of Directive 2004/38.

97. A. Tryfonidou, 'EU Free Movement Law and the Children of Rainbow Families: Children of a Lesser God?', 38 Yearbook of European Law 220 (2019)

98. Case C-148/02, Garcia Avello EU:C:2003:539. 
prohibits discrimination on the grounds of nationality in situations falling within the scope of application of the Treaties). In other words, the principle of non-discrimination requires - classically - that similar situations be treated in the same way but, also, that different situations must be treated differently.

Nonetheless, when the CJEU was presented with the opportunity to follow this approach in a case involving sexual orientation discrimination, it failed to do so. In Parris, ${ }^{99}$ at issue was the compatibility with Directive $2000 / 78^{100}$ of the requirement of an Irish pension scheme that in order for a member of that scheme to be able to designate his (same-sex or opposite-sex) spouse or registered partner as the person entitled to receive a survivor's pension in the event of the member's death, their marriage or registered partnership should have been concluded before the latter turned 60 . Ireland has allowed same-sex couples to enter into a registered partnership only from 1 January 2011, and same-sex registered partnerships contracted abroad can only be recognised from that date; same-sex marriage was introduced in Ireland in 2015, though the facts of the case arose before that date. The contested pension scheme requirement was, indeed, a universal condition that was applicable to both opposite-sex and same-sex couples. However, the legal disability for LGB persons in Ireland to enter into a same-sex registered partnership until 2011, combined with the universal age condition for designating someone's registered partner or spouse as the person entitled to a survivor's pension, meant that a specific group of LGB persons (i.e. those born before 1951) would be disadvantaged by being unable under any circumstances to provide for their same-sex registered partners in case they pre-deceased them. Same-sex couples were under a legal disability as they could not formalise their relationship in Ireland until a specific date; hence, this placed them in a different position from their heterosexual peers who did not face a similar legal disability. By treating these two - differently situated - categories of persons in the same way, the contested requirement, therefore, led to discrimination against same-sex couples who suffered a disadvantage as a result of the fact that their legal disability was not taken into account when formulating the rules of the relevant pension scheme. In its ruling, nonetheless, the CJEU dismissed the claim, noting that EU Member States are

free to provide or not to provide for marriage for persons of the same sex, or an alternative form of legal recognition of their relationship, and, if they do so provide, to lay down the date from which such a marriage or alternative form is to have effect. ${ }^{101}$

Hence, the Court chose to avoid dealing with the matter, allowing the perpetuation of discrimination on the grounds of sexual orientation caused by a pension scheme that did not take into account the different posi-

99. Case C-443/15, Parris EU:C:2016:897

100. Directive 2000/78, OJ 2000 L 180/22, above n. 54 .

101. Parris, above n. 99, para. 59 tions between opposite-sex and same-sex couples, when regulating the financial consequences ensuing from the legal recognition of relationships. ${ }^{102}$

Accordingly, if the CJEU is faced with a scenario in the future whereby LGB persons or same-sex couples are in a different situation from heterosexual persons or opposite-sex couples, it needs to take a pragmatic approach and look behind form in order to determine - first whether for a specific legal purpose these two different categories are differently situated, and if they are, then it should treat them differently, taking into account the difference in their position. This will, particularly, be the case in situations where a benefit or entitlement is reserved for married couples and marriage is not open to same-sex couples in the Member State concerned.

\section{Should European Law Wait for 'Hearts and Minds' to Change Before It Imposes More Positive Obligations?}

This section will examine whether European law should wait for 'hearts and minds' to change before it imposes on States additional positive obligations towards sexual minorities or whether it should impose such obligations without waiting for this, exactly in order to contribute to changing 'hearts and minds'.

The EU and the ECHR already, on paper, recognise that persons who have a minority sexual orientation have the same moral value as heterosexuals. This is obvious from the fact that they both prohibit discrimination on the grounds of sexual orientation, and - as regards the EU there is the requirement, seen earlier, laid down in Article 10 TFEU to combat discrimination based on sexual orientation 'in defining and implementing its policies and activities'.

However, in practice, the ECtHR and - at least for matters that fall within its competence - the EU do not conform to this. This is obvious from the fact that not all rights available to heterosexual persons and the traditional 'nuclear family' are available to LGB persons and rainbow families: in a number of areas, States are permitted to continue discriminating against sexual minorities. This is possibly because the ECtHR (and, perhaps, by extension the $\mathrm{EU}^{103}$ ) have viewed homosexual/bisex-

102. For a more detailed analysis of the case, see A. Tryfonidou, 'Another Failed Opportunity for the Effective Protection of the Rights of SameSex Couples Under EU Law: Parris $v$ Trinity College Dublin and Others', 2(2) Anti-Discrimination Law Review 83 (2017).

103. Although the ECHR is not an EU instrument, it has, nonetheless, always had a significant impact on the development of EU fundamental human rights protection, being recognised as a source of 'guidelines' for the CJEU when determining which fundamental human rights form part of the general principles of EU law and how these must be interpreted (Case 4/73, Nold EU:C:1974:51). In addition, the ECHR plays a crucial role in the interpretation of the EUCFR, as Art. 52(3) EUCFR provides that 
ual sexual orientation as an 'essentially private manifestation of human personality', which in turn has created severe limitations in the development of full rights for LGB persons: the latter enjoy the rights associated with the domestic sphere (e.g. to be able to have consensual sexual relationships with persons of the same sex in private) but are (still) deprived of the rights associated with social, public and institutional participation, such as the right to marry a person of the same sex and to be legally recognised - together with their same-sex partner/ spouse - as the joint legal parents of their child(ren). However, as has been rightly noted by another commentator, 'targeting on the ground of sexual orientation does not merely touch what is done in private; it taints the character of the LGBT person in the public sphere', ${ }^{104}$ as it sends out a message that LGBT persons can be discriminated against, which implies that sexual minorities are inferior, which is the root cause of homophobia. In addition, there is still considerable resistance among many people, organisations and governments to discussing the need for full enjoyment of human and other rights by LGB persons.

The main justification for not extending to LGB persons all the rights granted to their heterosexual peers is that there is no consensus among European states with regard to the enjoyment of those particular rights and, for this reason, the ECtHR and - where applicable - the EU cannot impose a positive obligation on signatory states with regard to these. This implies that the ECtHR and EU approach is that European law should wait for 'hearts and minds' - or, perhaps, more accurately, for the national legislatures' 'hearts and minds' - to change before additional positive obligations are imposed.

Nonetheless, the foregoing is not a good enough reason for absolving the ECtHR and - where applicable - the EU institutions from the need to protect the rights of sexual minorities in European States where these are not yet sufficiently protected. In particular, stereotypical perceptions about sexual minorities and the relationships of same-sex couples should not be perpetuated by the EU and the ECtHR and, most importantly, should not form the basis for the refusal of rights to which - as human beings (ECHR) or Union citizens (EU) - they should be entitled. As noted by Fenwick and Fenwick,

reliance on consensus analysis as linked to the width or narrowness of the margin of appreciation conceded to a state has the capacity to allow popular opinion in a number of Member States to affect the protection offered to sexual minorities adversely. ${ }^{105}$

In other words, by using consensus analysis, European law is allowing majoritarianism across European states

"[i]n so far as this Charter contains rights which correspond to rights guaranteed by the Convention for the Protection of Human Rights and Fundamental Freedoms, the meaning and scope of those rights shall be the same as those laid down by the said Convention. This provision shall not prevent Union law providing more extensive protection."

104. Laverack, above n. 78, at 178.

105. Fenwick and Fenwick, above n. 34, at 270. that deprives sexual minorities of certain of their most basic fundamental rights. However, the ECtHR and the EU institutions should not take part in the perpetuation of majoritarian oppression but should, in fact, lead the way in the fight against the oppression of LGB persons, by requiring changes in the (national) law that will demonstrate, exactly, that sexual minorities deserve the same respect - and are entitled to the same rights - as everyone else.

Reserving certain rights (such as the right to marry) only for heterosexual persons sends, exactly, the message that LGB persons are not worthy of the same treatment as is granted to their heterosexual peers, which implies that they constitute an inferior class of persons. Extending all rights to same-sex couples and LGB persons will send out a clear signal that discrimination against sexual minorities is not acceptable under any circumstances, which in turn will contribute to a diminution in the social acceptance of homophobia. After all, as the ECtHR noted in Bayev,

It is true that popular sentiment may play an important role in the Court's assessment when it comes to the justification on the grounds of morals. However, there is an important difference between giving way to popular support in favour of extending the scope of the Convention guarantees and a situation where that support is relied on in order to narrow the scope of the substantive protection. The Court reiterates that it would be incompatible with the underlying values of the Convention if the exercise of Convention rights by a minority group were made conditional on its being accepted by the majority. Were this so, a minority group's rights to freedom of religion, expression and assembly would become merely theoretical rather than practical and effective as required by the Convention. ${ }^{106}$

Accordingly, the EU institutions and the ECtHR should not wait for 'hearts and minds' to be changed before they can recognise the need for full enjoyment of human and other rights by LGB persons. Rather, they should impose additional positive obligations on States towards sexual minorities exactly in order to contribute to the fight for changing 'hearts and minds' with regard to this issue. ${ }^{107}$ It is true that awareness-raising and other educational activities are important in order to change 'hearts and minds' and the perception of sexual minorities by the broader society. ${ }^{108}$ Nonetheless, instead of waiting for societal (and national legal) approval of a certain minority before endorsing this approval at the European level, the EU institutions and the ECtHR

106. Bayev and others v. Russia, nos. $67667 / 09,44092 / 12$ and $56717 / 12$, 20 June 2017, para. 70. Alekseyev v. Russia, nos. 4916/07, 25924/08 and 14599/09, 21 October 2010, para. 81.

107. For an article considering whether legal developments can change hearts and minds see A. Böcker, 'Can Non-discrimination Law Change Hearts and Minds?', Erasmus Law Review 3, (2020).

108. D. McGoldrick, 'The Development and Status of Sexual Orientation Discrimination under International Human Rights Law', 16 Human Rights Law Review 613, at 667 (2016). 
should, exactly, require and push for such approval by demonstrating that discrimination against sexual minorities and other violations of their rights cannot be tolerated under any circumstances. ${ }^{109}$

\section{Conclusion}

This article set out to explore the positive obligations towards sexual minorities that European law imposes on European states. It is clear that the law should respect and protect all sexualities and diverse intimate relationships without discrimination and that for this purpose it needs to ensure that not only can sexual minorities be free from state interference when expressing their sexuality in private but that they should be given the right to express their sexuality in public and to have their intimate relationships legally recognised. In addition, sexual minorities should be protected from the actions of other individuals when these violate their legal and fundamental human rights.

It has been seen that, to date, European law has imposed on European states a number of positive obligations towards sexual minorities. Nonetheless, it has been shown that there is definitely still scope for more, if the ECtHR and the EU institutions are serious in their commitment to respect and protect the rights of sexual minorities.

It is true that when it comes to sexual minorities and the respect and protection of their rights under the law, Europe is a divided continent. Moreover, societal attitudes towards sexual minorities differ among European States, and these tend to go hand in hand with the approach adopted by the law: the more homophobic the population is in a State, the fewer (if any) rights LGB persons enjoy under the law.

One of the main questions explored in this article was, exactly, whether the EU and the ECtHR, should strive to achieve diversity mithin European States, by requiring all European States to fully respect the rights of sexual minorities, irrespective of the views of their population and of their lawmakers. In other words, should, for instance, all European states be required by European law to introduce same-sex marriage, irrespective of whether the society (and the lawmakers) in some of them do not appear ready to accept this? Or should European law continue to respect the diversity between European States as regards the rights of sexual minorities and allow a wide margin of appreciation - at least as regards some, more controversial, issues such as samesex marriage - in order to ensure that a change in the law is not forced upon the population and lawmakers of any European state, before it is felt that they are ready

109. For an argument that it is legitimate for the State to practise soft paternalism towards changing hearts and minds in order to prevent behaviour which is discriminatory on the basis of protected characteristics see Tourkochoriti in this special edition. for this? ${ }^{110}$ In other words, should European law impose changes in the law in order to change 'hearts and minds', or should it first wait for a change of (all) 'hearts and minds' in Europe in order to make it a European law requirement to extend to LGB persons the full gamut of rights that are currently enjoyed by their heterosexual peers?

The article has suggested that European law must protect vulnerable minorities who fail to receive protection for their rights domestically. In other words, European law should not wait for 'hearts and minds' to change before imposing additional obligations towards sexual minorities on European States, especially since this gives the impression that the EU and the ECtHR are condoning or disregarding persistent discrimination against sexual minorities.
110. This distinction between 'diversity within' States and 'diversity between' States has been borrowed from G.N. Toggenburg, 'Diversity Before the European Court of Justice: The Case of Lesbian, Gay, Bisexual, and Transgender Rights', in E. Prügl and M. Thiel (eds.), Diversity in the European Union (Palgrave Macmillan, 2009), at 136. 